\title{
EN MEMORIA DE Pedro Siller
}

VÍCTOR OROZCO

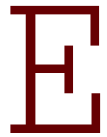

1 día 26 de septiembre falleció en Ciudad Juárez Pedro Siller, chiapaneco de origen, nacido en 1951 e hijo adoptivo de esta ciudad como tantos, entrañable amigo e historiador de altos vuelos. Su partida deja un hueco en los estudios históricos de México. Lo conocí hace unos treinta años, cuando envió algunos textos a la revista Cuadernos del Norte, en la cual, decía festivamente, comenzó su carrera como escritor "chihuahuense".

Dejó constancia de varias de sus virtudes en el oficio de quienes buscan desentrañar y entender el pasado.

Una vez que asumía un tema, trabajaba incansablemente en el conocimiento del mismo y difícilmente asumía que lo había agotado o que era tiempo de concluir y darle la vuela a la hoja. En este sentido, no era de los autores apresurados, que se ponen fechas en función de acontecimientos ajenos al proceso de investigación y escritura, como celebraciones o efemérides. El libro se debe terminar cuando se acabe, valga el pleonasmo. En los largos años que le llevó su monumental obra "Rebelión en la Revolución. La revolución en Chihuahua 1910-1914” le hacía la broma de que estaba como la viejita que no quería vender todos los dulces, porque "después qué vendía”. Lo celebraba con risas y me decía: "Pues es que ya me encontré otra veta, qué quieres". Debemos deplorar que no haya vivido para ver su trabajo impreso o digital sobre la Decena Trágica, en el cual se empeñó desde hace por lo menos un lustro. Ojalá que alguien tomara la estafeta y lo publica-

1 Maestro Emérito de la UACJ y miembro de la Academia Mexicana de la Historia. 
ra, pues me constan la riqueza y abundancia de las fuentes sobre las cuales indagó.

Otro de sus méritos es la rigurosa crítica del material histórico con el cual laboraba. Nunca se conformaba con un testimonio o tesis, por más aceptados e incluso sacralizados que estuvieran. Escarbaba y escarbaba, colocando una lupa sobre cada versión histórica a la manera de una disección.

Bibliófilo consumado, conocía los vericuetos de las publicaciones y se afanaba por tenerlas a su alcance, sobre todo en las bibliotecas públicas, como la Central de la Universidad Autónoma de Ciudad Juárez, a la que enriqueció proponiéndole la adquisición de títulos relevantes. Con la llegada de las bibliotecas digitales, Pedro se encontró en un mar abierto para sus navegaciones. Bajó, como se dice hoy, incontables libros y artículos. Una ocasión, en sus frecuentes visitas a mi oficina en la UACJ, me entregó una memoria con más de mil títulos de libros difíciles de adquirir. Este acto revela también otro de sus distintivos personales: su generosidad. No tenía reparos en compartir materiales y hallazgos.

A lo largo de los años estuvimos juntos en varios escenarios. Me honró nombrándome codirector de su tesis de doctorado, fue miembro del Comité Editorial de Cuadernos Fronterizos en donde compartimos la redacción de la sección "El Baúl”, formada con documentos y curiosidades históricas y a mi retiro de la UACJ en 2020, se encargó fugazmente de la dirección de la obra colectiva Chihuahua Hoy. Visiones de su historia, economía, política y cultura con la colaboración de Erika Sena. Desafortunadamente su salud empeoró en ese tiempo y solo alcanzó a publicar el volumen correspondiente al mismo año.

También conocí de cerca su labor como maestro de Historia. Le interesaba alentar en los estudiantes una vocación por la cultura universal. A veces se empezaba la clase escuchando una pieza de Beethoven u otro clásico. También les dejaba de lectura pasajes de la llíada, presuntamente muy alejados de la temática del programa. Varios se beneficiaron grandemente de sus enseñanzas y se convirtieron en investigadores. 
Además de su libro ya nombrado, publicó la novela Materia de Sombras, la Batalla de Ciudad Juárez e innumerables artículos en revistas especializadas.

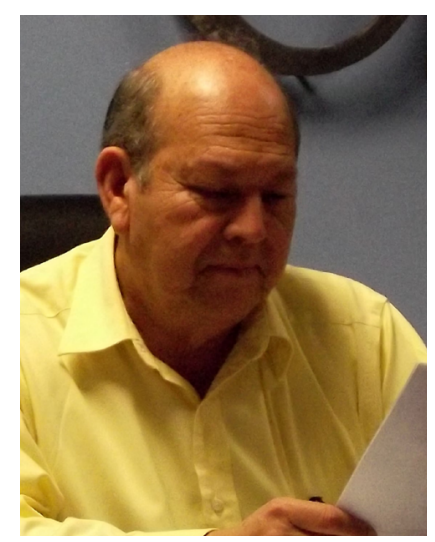

Foto de Archivo.

Estamos de luto. Descanse en paz Pedro Vidal Siller. 